\title{
KRISIS LINGKUNGAN DALAM PERSPEKTIF SPIRITUAL ECOLOGY
}

\author{
Supian* \\ Surel:
}

\begin{abstract}
The reality of the crisis and environmental degradation is a major problem that the world's population is facing today. Experts argue that the current crisis and environmental degradation are closely related to the mentality and misconceptions about the environment itself. Long debates and intense discussions, especially between science and religion, are intensively undertaken in an attempt to find a way out of the ongoing environmental degradation. Various perspectives arise and are expected, including from the spiritual ecology approach, to rethink the relationship between man and the earth, or on a wider scale, the relationship between man and the earth in the corridor of cosmic cosmic beliefs as his philosophical basis. The emergence of environmental crisis is caused by the concept of the relationship between humans and the natural environment is wrong. The problem of environmental damage is essentially a humanitarian problem that is closely related to the value system, customs and religion in human life. Therefore, the way to overcome it is not enough just to do business that is purely technical, but more importantly there must be a business that is educative and persuasive, that is with a philosophical understanding of the meaning of nature's existence in relation to God, man and nature, to change attitude and human behavior towards nature.Many even consider the need for a spiritual revolution to save nature and the environment, which is now at a spiritual stage of spirituality and then offers the application of the concept of eco-spirituality. ie to incorporate spiritual values in aspects of human environmental studies, where religion has a very dominant role. This paper delivers bluntly what are the causes of environmental damage in the spiritual ecology approach.
\end{abstract}

Keywords: Spiritual Ecology, Environmental Crisis, teleology, the universe

\section{PENDAHULUAN}

*Dr. Supian, S.Ag., M.Ag.Dosen FKIP Universitas Jambi. 


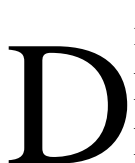

i dalam Islam, hubungan,

keserasian

keharmonisan

dan

antara

mikrokosmos

dan

makrokosmos merupakan bagian penting dalam debat pemikiran Islam, sejak masa awal hingga saat ini, seperti dalam teologi, filsafat dan tasawuf, sehingga alam dan lingkungan hidup dalam ajaran Islam merupakan bagian tak terpisahkan dan memiliki nilai spiritual (spiritual ecology).

Seyyed Hossein Nasr(dalam Muzaffar Iqbal : 2007)yang terkenal dengan gagasannya tentang $a$ sacred science atau sains yang sakral, meneriangkan bahwa berdasarkan pengetahuan profetis Islam, maka manusia diharuskan untuk tidak menaklukkan alam, dalam arti mengeksplorasi dan mengeksploitasi sumber daya alam secara brutal. Namun manusia dapat memanfaatkan sumber daya alam sesuai dengan perintah Allah. Dalam konteks ini Nasr mengkritisi modernisme yang menurutnya memiliki ambisi untuk menguasai alam, dan hal itu hanya akan berakhir pada krisis lingkungan. Melhiat realitas tersebut, menurut Abdul Quddus (2011) harus ada resakralisasi alam yang berbasis pada nilai-nilai dan tradisi spiritualitas keagamaan. Hal ini dimaksudkan untuk mendekonstruksi sains modern yang bersifat sekuler, yang memposisikan Tuhan sebagai redundant hypothesis dan memperlakukan alam sebagai objek dan benda mati yang dapat saja dieksploitasi tanpa batas.

Nawal Ammar(2001 : 193) yang menulis tentang "Islam and Deep Ecology", antara lain menyebutkan bahwa terjadi miskonsepsi (misconceived) dan misinterpretasi (misinterpreted) di kalangan umat Islam dalam memahami hubungan antara agama dan ecology, oleh karena itu pada dekade terakhir abad ke 20, dipandang perlu adanya teologi baru (new theology) atau reformasi pemahaman agama dalam menyusun sebuah visi baru mengenai ecology yang ia namakan sebagai alam atau bumi baru (new earth). Bahwa bumi ini adalah ciptaan Tuhan, dan segala ciptaan Tuhan itu harus dipelihara, dimuliakan dan disayangi, menyayangi bumi berarti juga menyayangi Tuhan dan merusak bumi berarti tidak menyayangi Tuhan, dan ia mengajukan premis, "everything on earth is created by God, everything that God creates reflects His sacredness, and that every thing on earth worships the same God"

Menurut Nawal Ammar, hubungan (relationship) dan interaksi antara manusia dan alam lingkungannya merupakan hubungan spiritualitas rasional yang menggambarkan nilai-nilai kedamaian alam, keindahan, tanggung jawab moral dalam menjaga lingkungan, perlindungan 
dari setiap kerusakan dan kehancuran lingkungan, dan pembangunan serta penghijauan kembali atau revival alam dan lingkungan yang sudah rusak. Hubungan ini merupakan kewajiban moral dan kewajiban spiritual setiap manusia, manusia hendaknya menjadikan alam dan lingkungannya di dunia ini layaknya taman keindahan yang ia nikmati di syurga. Oleh karena itu Islam juga menurutnya sangat mengedepankan perspektif tersebut yang ia sebut sebagai a deep relational perspective on natural and social ecology.

Secara filosofis, Bruno Guiderdoni (2001) menjelaskan bahwa makna yang paling utama dari pemahaman tentang teleologi kosmis, bukanlah untuk meneliti tentang alam, tetapi bagaimana manusia bersikap dalam mengelola dan hidup bersama alam dengan spirit dan nilai-nilai ilahi (the action within the world in God's name). Perspektif inilah yang dapat dijadikan inspirasi filosofis lebih luas dan lebih mendalam mengenai hubungan antara keyakinan teleologis mengenai alam dan implikasinya terhadap cara pandang, mentalitas, sikap dan prilaku manusia terhadap alam dan lingkungannya yang sering disebut deep ecology, eco-philosophy dan ecosophy.

Henryk
"pendiri"

menceritakan bahwa sejarah munculnya ide menuju konsep ecophilosophy bermula dari tahun 1970-an, tepatnya tahun 1974, ketika ia menyadari bahwa ada kesalahan tentang cetak biru filsafat, yang meletakkan filsafat mekanistik menjadi basis peradaban dunia, akibatnya alam diasumsikan sebagai mesin, ilmu pengetahuan (sains) menjadi kekuatan utama dan alam menjadi milik manusia sepenuhnya untuk eksploitasi dan penjarahan. Ada konsep dan idiom yang salah tentang interaksi antara manusia dengan alam (we simply conceived of a wrong idiom for the interaction with nature), yang kemudian menginspirasinya untuk menyusun pendekatan baru filsafat dalam hubungannya dengan alam,sehingga pada tahun 1981 ia menulis bukunya tentang eco-philosophy ${ }^{2}$.

Konsep sentral ecophilosophy yang diajukan oleh Skolimowski (Henryk Skolimowski, "What is Eco-Philosophy? Some Founding Principles", dalam http://home.cogeco.ca/ drheault/ee readings/Environmental_Ethics_Soc iety/SkolimowskiWhat_is_Eco_phil osophy(pdf). Diunduh tanggal 30 Oktober 2011) adalah "alam sebagai

${ }^{2}$ Henryk Skolimowski, "Eco-
Philosophy in an Historical
Perspective",yang ia tulis pada Februari
2008,
http://www.ecophilosophy.org/new/articles/
090214 history.html, diunduh tanggal 29
Sept 2011. Buku yang ia maksud adalah
Eco Philosophy: Designing New Tactics for
Living.


sebuah suaka" (the world as sanctuary), ini merupakan visi utama sebagai alternatif yang ditawarkan untuk mereposisi visi Newtonian bahwa "alam sebagai mesin" (world as a machine). Konsep ini harus menjadi pandangan baru (newworldview) di samping empat konsep kunci ecophilosophy yang lain, yakni (i) nilai penghormatan terhadap kehidupan (reverence for life is our guiding value), (ii) hemat sebagai prasyarat kebahagiaan batin (frugality is a precondition for inner happiness), (iii) spiritualitas dan rasionalitas tidak meniadakan satu sama lain, tetapi saling melengkapi (spirituality and rationality do not exclude each other but complement each other), dan (iv) untuk menyelamatkan planet atau alam ini maka harus menyelamatkan manusianya (in order to heal the planet we must heal ourselves).

Tentu saja dibutuhkan refleksi yang panjang, nilai-nilai filosofis dan penyesuaian bagi kepekaan religius untuk dapat berfikir secara konsisten mengenai apa kiranya penyebab terjadinya kerusakan lingkungan ini dalam kacamata filsafat modern, yang kemudian menginspirasi tulisan "Krisis Lingkungan dalam Perspektif EcoPhilosophy” ini.

\section{PEMBAHASAN}

Sebab Filosofis Krisis Lingkungan

Dalam beberapa dekade terakhir, telah banyak dilakukan berbagai studi tentang krisis lingkungan yang telah melanda dunia dan tentu saja termasuk manusia di dalamnya, telah pula dilakukan berbagai upaya penyelamatan dan konservasi lingkungan untuk mengatasi krisis lingkungan tersebut. Dan dunia, tak terkecuali Indonesia, semakin getol pula memakai kata-kata "eco" atau "green" dalam semua aspek aktivitas kehidupan manusia untuk menggambarkan kerinduan manusia akan alam semesta yang asri dan asli sebagaimana sedia kala.

Dari berbagai studi itu, menurut Nasr (1968), hanya sedikit yang berusaha secara mendalam menggali sebab-sebab intelektual dan filosofis krisis tersebut, sehingga membuat krisis modern yang sangat mengancam eksistensi alam semesta dengan segala isinya ini menjadi semakin akut. Padahal apabila dirunut sebab-sebab sejarahnya, krisis dan penyakit ini sebagian besar disebabkan atau ditimbulkan oleh sains dan pemikiran filsafat modern serta penerapannya, sehingga sangat logis apabila juga merunut "terapy penyembuhannya" melalui sains dan pemikiran filsafat pula. Berbagai deklarasi, konvensi, ide dan gagasan internasional tentang lingkungan dan konservasi alam masih 
dirasakan kurang "manjur" dalam mengurangi krisis ini, masih dirasakan ada yang kurang untuk menghasilkan perubahan dalam memandang krisis ekologis ini secara menyeluruh.

Menurut kajian Armely

Meiviana (2004), kebijakankebijakan administratif dan teknis yang sudah diterapkan di banyak negara, belum memasukkan faktor filosofis sebagai worldview dunia ke dalam salah satu aspek yang harus dikembangkan. Meskipun di sisi lain sudah sangat disadari bahwa ada faktor lain yang harus diikutsertakan. Algore umpamanya (1992), meyakini bahwa penyebab krisis ekologi global ini adalah karena krisis spiritual. Manusia salah dalam memahami posisi dan kedudukannya dalam ciptaan dan ekosistem, sehingga ketika ingin mengatasi krisis lingkungan, faktor spiritual tidak bisa ditinggalkan.

Shierry Weber Nicholsen (2002) dalam pengantar bukunya The Love of Nature and the End of the World, mengatakan bahwa di luar ancaman perang nuklir, maka krisis lingkungan merupakan ancaman terbesar yang dihadapi umat manusia secara kolektif dewasa ini. Ia menambahkan hipotesisnya itu dengan menyatakan bahwa manusia dunia memiliki sikap apatis yang sangat parah dan meluas (severe and pervasive apathy), seolah-olah tidak menyadari (unconscious) ancaman tersebut dan memelihara kebodohan yang disengaja (willfull stupidity).

Gambaran menakutkan dari krisis lingkungan, seolah-olah terus menghantui penduduk dunia, ancaman krisis lingkungan masuk ke dalam ancaman yang sama menakutkannya dengan ancaman peperangan dan terorisme, bahkan Douglas Long (2004) menyebutnya sebagai ecoterrorism, sehingga secara filosofis perlu untuk dikemukakan penyebab terjadinya krisis lingkungan dan menyoroti sebab-sebab esensial dan mendasar, sehingga dapat pula menjadi dasardasar perubahan sikap, pandangan dan pola pemikiran banyak orang yang telah melihat dan merasakan langsung pengaruh buruk dari sebab-sebab tersebut.

Karena menurut Seyyed Hossein Nasr (2007), meskipun sains itu sendiri absah, namun peran dan fungsi sains serta penerapannya dapat saja tidak absah lagi, bahkan bisa saja justru berbahaya, jika tidak ada bentuk pengetahuan yang lebih tinggi (di mana sains terintegrasi di dalamnya) dan jika nilai alam yang bersifat sakral dan spiritual telah dihilangkan. Untuk mengatasi masalah ini, pegetahuan filsafat dan metafisika yang berkenaan dengan alam harus kembali dihidupkan, sejarah dan filsafat yang berhubungan dengan teologi serta filsafat alam tradisional harus diteliti kembali. 
Penyebab terjadinya krisis lingkungan secara filosofis antara lain;

\section{Dominasi Manusia atas Alam}

Dominasi manusia terhadap alam (domination of nature) dipercaya sebagai salah satu penyebab krisis lingkungan, Seyyed Hossein Nasr menjelaskan bahwa di antara dosa-dosa warisan dominasi terhadap alam tersebut adalah masalah kelebihan penduduk, kurangnya "ruang bernafas" (breathing space), kepadatan dan kemacetan kehidupan kota, pengurasan segala jenis sumber daya alam, hancurnya keindahan alam, perkawinan lingkungan hidup dengan alat mesin dan produknya, munculnya penyakit mental yang tidak normal dan seribu satu kesulitan, keadaan dan akibat lain dari dominasi terhadap alam tersebut.

Dalam keadaan lingkungan seperti ini, menurut M. Eliade (1959: 179) orang beragamapun telah kehilangan arti spiritualitas alam. Alam semesta tidak lagi diposisikan, apalagi dirasakan sebagai karya Tuhan. Alam menjadi sesuatu yang tanpa makna, dan pada saat yang sama arti dominasi atas alam yang dianut oleh manusia modern didukung dengan nafsu dan ketamakan yang semakin banyak menuntut pada lingkungan. Dan dengan didorong oleh impian yang elusif (elusive dream) tentang kemajuan ekonomi yang dianggap sebagai tujuan, lalu muncullah sebuah arti kekuasaan manusia (atas alam) yang tidak terbatas.

Henryk Skolimowski (2008 : 30-31) menjelaskan bahwa salah satu karakteristik filsafat kontemporer adalah selalu menghubungkan atau mengambil alasan ekonomi dan kemajuan materialistik (related to the economics of material progress), padahal dalam pendekatan ecophilosophy pendekatan ekonomi harus dihubungkan dengan kemajuan kualitas hidup (related to the economics of the quality of life). Kemajuan ekonomi yang tidak berorientasi ekologis merupakan harapan jangka pendek, karena ketika aspek ekologisnya telah rusak, maka dengan sendirinya kemajuan ekonomi tersebut akan mengalami keruntuhan.

Ada pula pendapat yang meng-kambinghitam-kan nilai agama, yang karena memiliki aspek eskatologis, akan mempunyai orientasi yang melalaikan lingkungan, bersikap ambivalensi atau bahkan bersikap dominan terhadap alam. Karena mengapa manusia harus repot-repot menjaga kelestarian alam dan lingkungannya, menjaga kelestarian burung dan binatang lainnya, hutan dan tanaman lainnya atau membersihkan sumber air dan udara, sementara perhatian utama kehidupan religius adalah untuk mempersiapkan diri bagi kehidupan di alam berikutnya. 
Pandangan mengenai alam ini diciptakan hanya untuk tujuan kebutuhan manusia, dianggap dominan di dalam tradisi Islam.

"Tudingan" ini menunjukkan kekeliruan penafsiran terhadap teksteks suci tersebut, karena memang Tuhan menciptakan alam untuk manusia, tetapi tidak harus menjadi tirani atas alam, karena dengan melakukan eksploitasi atas alam, justru akan mengakibatkan kerusakan alam dan semakin terbatasnya alam untuk kebutuhan manusia itu sendiri. Di samping juga tidak mengutip ayat-ayat yang menunjukkan keharusan untuk memperhatikan alam dan lingkungan. Bahwa harmoni antara manusia dan alam semesta telah dihancurkan, antara lain akibat keserakahan dan dominasi manusia atas alam, merupakan sebuah fakta yang diakui oleh sebagian besar orang, apalagi dengan "dukungan" sains dan teknologi, dominasi itu cenderung "semakin menjadi-jadi". Tetapi tidak banyak orang yang menyadari ketidakseimbangan atau ketidakharmonisan itu, suara protes dari kaum konservasionis dan pecinta alam tidak sepenuhnya terdengar, karena argumen mereka sering dianggap sentimental daripada intelektual. Sedang para pemikir, filosof dan teolog sebagian besar tetap berdiam diri atau menghindar dari serangan mood ilmiah yang umum sekarang ini. Jarang muncul suara yang menunjukkan bahwa kepercayaan mutakhir tentang dominasi alam merupakan perampasan peran manusia sebagai pemelihara dan penjaga alam (Hossein Nasr, 2007 : 19-20)

\section{Eksploitasi Sumber Daya Alam}

Lanjutan dari dominasi manusia atas alam, adalah eksploitasi atas sumber daya alam oleh manusia, dan bahkan sebenarnya keduanya merupakan sebab akibat yang tidak terpisahkan, dominasi manusia atas alam mengakibatkan terjadinya eksploitasi sumber daya alam, atau dengan bahasa lain, bahwa eksploitasi sumber daya alam karena dominasi manusia atas alam. Bedanya terletak pada penekanan aspek yang menjadi sebab krisis lingkungan secara filosofis, di mana dominasi manusia atas alam lebih besar disebabkan pada faktor nilai dan doktrin, yang terpusat kepada manusianya, sedangkan eksploitasi sumber daya alam lebih besar disebabkan oleh faktor ekonomi dan politik, yang terpusat kepada alam lingkungannya. Dengan kata lain, dominasi atas alam terjadi akibat krisis pemahaman, sedangkan ekploitasi atas alam terjadi akibat krisis penerapan.

Roy W. Spencer (dalam Mulyadi kartanegara, 2009 : 156) merilis bahwa saat pertama kali dilakukan survey dengan pertanyaan; "Has human activity 
been a significant factor in changing mean global temperatures?" (Apakah aktivitas manusia menjadifaktor signifikan dalam perubahansuhu global? ), Jawaban yang didapat hampir menggambarkan bahwa terjadi konsensus ilmiah para ilmuan (85\%) yang memiliki keyakinan dan menyatakan bahwa pemanasan global (global warming) adalah proses atau siklus alami alam, sehingga pada awalnya ini menjadi pemahaman yang luas di tengah masyarakat. Angka itu kemudian menurun menjadi $44 \%$ dan sembilan bulan berikutnya menjadi $34 \%$. Hingga akhirnya sekarang keadaan menjadi berbalik, konsensus ilmiah menunjukkan bahwa global warming terjadi akibat aktivitas manusia.

James Hansen (Dalam Mudofir, 2009 : 48-49), ilmuan NASA ternama, pada tanggal 23 September 2008 mengatakan bahwa, jika eksploitasi sumber daya alam terus menerus terjadi, dan jika pengurangan emisi karbondioksida di bawah kendali, maka "kita sedang menghancurkan alam ini" (we are going to derstroy the creation). Jika dunia tidak bisa menghentikan aktivitas eksploitasi alam, terutama yang sering disebut sebagai revolusi industri, terutama oleh perusahaanperusahaan yang melakukan eksploitasi sumber daya alam dan tidak menyerukan penghentian pembangunan yang tidak ramah lingkungan, maka hal itu merupakan pertanda bahwa sedang terjadi kesalahan dan kejahatan besar terhadap manusia dan alam.

Eksploitasi terhadap alam dan lingkungan, secara filosofis disebabkan oleh tidak ada keseimbangan antara manusia dan alam serta "dukungan" sains yang dalam pengertian lain merupakan sebab utama krisis perjumpaan manusia dan alam di masa sekarang ini. Alam semesta menjadi tersekulerisasikan dan kemudian dipisahkan dari visi tentang spiritualitasnya. Sehingga hampir semua ekspresi peradaban modern justru berusaha menawarkan ekploitasi terhadap alam, bukan mengajak alam untuk bekerjasama.

Sejatinya, menurut Hadi Alikodra (2012 : 25) Tuhan menciptakan bumi dengan segala isinya adalah untuk kesejahteraan umat-Nya. Namun Tuhan tetap meminta manusia untuk memelihara dan menjaganya, agar jangan sampai terjadi eksploitasi, kerusakan ataupun kemunduran sumber daya alam dan lingkungannya. Sesuai dengan kemajuan akal dan pikiran, serta teknologi yang dimilikinya, manusia telah mengeksploitasi sumber daya alam bagi pemenuhan kebutuhan hidupnya. Pertumbuhan penduduk yang pesat dengan pembangunannya yang tak terkendali telah banyak menyebabkan penipisan dan 
kerusakan sumber daya alam serta pencemaran lingkungan hidup.

\begin{tabular}{llr}
\multicolumn{2}{c}{ Eksploitasi } & berarti \\
memanfaatkan & alam & tanpa \\
diimbangi & dengan & aspek
\end{tabular}
keterpeliharaan dan konservasinya, itu berarti perbuatan yang merusak alam dan melawan "Sunnah" Tuhan terhadap alam. Padahal Tuhan menciptakan alam dengan segala kesempurnaan dan keteraturannya untuk kepentingan manusia dalam jangka panjang, alam semesta memiliki implikasi filosofis dan teologis bagi manusia. Makna teleologis alam yang diciptakan Tuhan merupakan nilai keterpeliharaan alam itu sendiri, dan manusia sebagai bagian dari alam yang diamanahkan Tuhan untuk memelihara alam, memiliki tanggung jawab untuk menjaga alam dan lingkungannya. Bukan sebaliknya malah merusak dan mengekploitasinya.

Itulah sebabnya sains dan ilmu kealaman harus memiliki signifikansi filosofis dan teologis, jika tidak maka sains akan semakin membawa keterpurukan alam karena penerapannya yang tidak mengindahkan nilai "ilahi" alam. Sains atau temuan ilmiah yang tercerabut dari nilai-nilai agama, dapat dengan sukses mengantarkan manusia untuk mengeksploitasi alam, tetapi ketika alam sudah berada di tepi jurang kerusakan akibat eksploitasi tersebut, sains kemudian seolah-olah lepas tangan dan mengembalikan tugas kelanjutannya kepada agama dan filsafat. Sebaliknya sains yang menjalankan "misi" Tuhan, maka tatanan alam semesta ini diidentifikasi dengan "pikiran" Tuhan, seorang saintis disebut menemukan "pikiran" Tuhan dalam penyelidikann ilmiahnya, dan metode ilmiah itu sendiri dapat disebut penemuan "pikiran" Tuhan.

\section{Alam sebagai Objek}

\section{Materialistik}

Mengutip tulisan Jurgen Moltmann (1997 : 28), "scientific and technological civilization is undoubtedly the most terrible monster ever to appear on earth". Bahwa peradaban ilmiah dan teknologi tidak diragukan lagi merupakan monster yang paling mengerikan yang pernah muncul di muka bumi ini. Hubungan kehidupan antara manusia dengan alam, menjadi tidak seimbang, karena alam kemudian hanya dijadikan sebagai objek materialistik semata. Sains dan tekonologi yang harusnya menjadi daya dukung dalam kehidupan ekologis manusia, berbalik menjadi aksesoris sifat materialistik manusia, manusia mengekploitasi alam dengan sains dan teknologi untuk mendapatkan materi sebanyak-banyaknya.

Pemahaman ini sebenarnya bermula dari paham materialisme, yang melihat dunia ini hanya sebagai materi (as a wholly material 
phenomenon) dan membuang jauhjauh semua yang bersifat immateri, setiap bagian dari eksistensi taat kepada hukum-hukum fisika tanpa memerlukan kontrol eksternal. Menurut David Ray Griffin (2000 : 31-32), inilah yang menjadikan "materialisme ilmiah" selalu bertabrakan dengan keyakinan agama. Dengan mengutip pendapat Edward O. Wilson, "scientific materialism" yang disebut juga "scientific naturalism" melihat alam semesta ini telah ditentukan oleh sebab-sebab mekanis, bahwa ide-ide dan nilai-nilai moral serta tujuan tidak memiliki dasar dalam kenyataan dan tidak memainkan peran dalam alam semesta.

Perilaku atau sifat manusia yang hanya berorientasi fisik material semata seperti itu, kontras dengan karakteristik eco-philosophy. Menurut Hendryk Skolimowski (2008 : 33), hal tersebut adalah penyimpangan dari makna kehidupan manusia, karena memaknai kehidupan terbatas kepada aspek konsumsi, aspek fisik, aspek biologi dan aspek ekonomi saja. Manusia meniadakan aspek alam trans- physic, aspek estetika, aspek kecintaan terhadap alam, dan reungan yang lebih dalam (deeper illumination), hingga aspek transendental dan trans- objective dari keberadaan manusia dan alam semesta, yang hanya bisa didapat dan dirasakan dari unsur spiritual dan pengalaman religius.
Konsepsi alam materialistik ini makin meneguhkan peran dominasi manusia atas alam dan menaklukkan alam. Bakat praktis dan utilitarian manusia makin terealisasi dan makin memberikan justifikasi kepada manusia sebagai makhluk bumi dengan tanpa tujuan selain mengekploitasi dan menguasai kekayaan alam untuk, sebagaimana Nasr, memenuhi nafsu dan kebutuhannya sebagai "binatang" yang dikaruniai akal dan pikiran analitik. Sehingga harus dibangun kembali sebuah ikatan filosofis yang dekat dengan alam, dengan "ruh" yang menghuni alam dan dengan Zat yang menciptakan dan mengatur alam semesta ini. Sebuah panggilan filosofis yang dapat mempersembahkan diri pada tema tentang alam lingkungan serta signifikansinya bagi manusia.

\section{Alam sebagai Mesin}

Dalam pandangan filosofis, pandangan yang menempatkan alam semesta sebagai mesin (nature as a machine) tentu saja berpengaruh besar terhadap sikap manusia kemudian kepada alam semesta. Ada dua aliran atau teori besar yang dapat dikategorikan ke dalam kelompok ini, yakni "hukum alam" atau "hukum mekanik" yang ditemukan oleh Isaac Newton, dan teori "evolusi" atau "teori seleksi alamiah" yang ditemukan atau dipelopori oleh Charles Darwin. Kedua konsep pemikiran "besar" ini 
melihat dan menempatkan alam semesta berdiri sendiri tanpa "melibatkan" Tuhan.

Gagasan tentang "hukum alam" yang sering disebut juga "hukum mekanik" memberikan gambaran bahwa alam semesta ini dianggap -atau merupakan - sebuah mesin raksasa, yang dikendalikan dan bekerja berdasarkan hukum alam, bukan merupakan "karya" atau desain Tuhan yang menciptakan dan mengatur alam semesta ini. Menurut pandangan ini alam bertindak sesuai dengan hukum-hukum impersonal yang dapat diekspresikan secara matematis, dan secara operasional menentukan segalanya. Apabila seseorang dapat mengukur massa, posisi dan kecepatan partikel dasar pada suatu waktu, dengan menggunakan hukum-hukum umum, ia akan dapat meramalkan apa yang akan terjadi secara persis. Gagasan ini menjadi pandangan yang sangat penting yang menyebabkan hukum mekanik dan sains modern "melejit" di muka bumi ini (Keith Ward, 2002 : 86).

Sedangkan gagasan tentang evolusi atau seleksi alamiah, spesies-spesies (baik tumbuhan maupun hewan) muncul bukanlah hasil dari kreasi agen dari luar dirinya (yang disebut Tuhan), tetapi sebagai adaptasi mereka terhadap tuntutan dari seleksi alamiah. Menurut Darwin, agar sebuah spesies bisa bertahan hidup, ia harus berusaha mengadakan transmutasi secara evolutif, seperti munculnya spesies baru. Jadi, adalah dorongan alamiah yang menyebabkan timbulnya spesies-spesies tersebut, dan sama sekali bukan hasil karya atau desain Tuhan atau agen apapun yang transenden di balik alam semesta ini

Dalam analisa Skolimowski, filsafat yang tidak memiliki nilai spiritual (spiritually dead) seperti itu tidak mencerminkan filsafat yang ramah lingkungan. Dan dilihat dari skala evolusi, spiritualitas merupakan "instrumen" menuju kesempurnaan manusia. Artinya tanpa unsur spiritualitas, manusia tidak akan bisa sampai pada titik kesempurnaan, dan apabila tanpa "melibatkan" Tuhan dalam semua gerak kosmik alam semesta ini, maka manusia juga tidak akan bisa mencapai kesempurnaan, baik inheren terhadap dirinya maupun sikapnya terhadap makhluk lain, khususnya terhadap alam semesta.

Seperti diketahui, bahwa dalam ekologiat au alam semesta, kerangka yang diasumsikanjauh lebih luas dari pada referensi dalam fisika atau kimia. Deskripsi fenomena fisika atau kimia tidak bisa dilakukan persis ketika berada dalam bingkai ekologis. Evolusi menyediakan kerangka yang lebih luas, termasuk evolusi budaya dan sikap manusia. Jadi konsep tentang kebenaran harus terkait dengan kerangka evolusi yang lebih luas, 
tidak hanya deskripsi statis dalam teori evolusi, artinya teori evolusi dan hukum alam membuat "evolusi" pandangan manusia terhadap alam semesta, yang dapat berpengaruh kepada tingkat persaingan manusia terhadap alam lingkungan untuk mendapatkan kehidupan yang lebih baik dan bersikap antipati kepada alam semesta, karena semuanya sudah merupakan hukum alam yang pada gilirannya akan dapat terseleksi dengan sendirinya oleh hukum alam.

Dengan kecenderungan manusia yang hanya melihat aspek fisiknya saja dan mengabaikan aspek spiritual dan keilahian ketika berbicara tentang alam dan lingkungan, maka alam menjadi tersekulerkan, dan ini akan menjadi basis filosofis "retaknya" hubungan manusia dengan alam, karena dengan pandangan seperti ini manusia dengan mudah menciptakan gangguan-gangguan atas tatanan alam, manusia semakin teralienasi dari alam, manusia menjadi tirani atas alam, manusia semakin bebas mengekploitasi alam dan semakin mengukuhkan perannya sebagai subjek dan alam sebagai objek, keadaan yang sering disebut sebagai antropocentrisme. (Van Plumwood, 2002 : 123)

Spiritualitas alam semesta berkontribusi besar dalam mengembangkan etika dan budaya praktis manusia terhadap alam dan lingkungannya. Sebagai sebuah gambaran sederhana saja, ketika ada keyakinan suatu daerah tentang suatu tempat yang memiliki nilai spiritual (seperti hutan atau tanah yang dianggap suci), sebagai instrumen non- duniawi yang lebih tinggi, maka tempat tersebut menjadi sesuatu yang harus dijaga dan dihormati. Keadaan seperti ini sering disebut sebagai local wisdom, yang apabila gambaran ini bisa diterapkan kepada seluruh alam dan lingkungan, dengan meyakini Tuhan sebagai spiritualitas tertinggi, maka seluruh alam semesta menjadi bagian yang harus dihormati dan dijaga.

Tetapi dengan berasumsi, menganggap dan meyakini bahwa alam semesta ini merupakan mesin raksasa yang dapat berjalan dengan sendirinya, maka manusia menjadi tidak peduli dan tidak sayang kepada alam semesta. Manusia hanya melihat alam dari fungsi dan sesuatu yang dihasilkannya. Bahkan manusia dapat memajukan penyangkalan dan distorsi epistemik, bahwa menantang anthropocentrism tidak relevan dan tidak membantu dalam menyelesaikan persoalan krisis lingkungan yang semakin akut ini. Dan kalau hal seperti ini yang terjadi, maka akan sangat berbahaya dalam konteks dunia sekarang ini (especially dangerous in our present global context). 


\section{Alam Tanpa "Campur Tangan" Tuhan}

Bagi kaum naturalis seperti Laplace dan Darwin, serta filosoffilosof atheistis lainnya, alam semesta ini tercipta dan beroperasi tanpa ada hubungannya dengan Tuhan. Begitu juga bagi materialisme, segala yang ada hanyalah materi dalam ruang, yang tidak ada tujuan dan makna dalam alam semesta. Segala kejadian dan fenomena alam tidak perlu dan tidak pernah "melibatkan" Tuhan, harmoni atau keserasian serta keteraturan dan kesempurnaan alam semesta ini hadir di muka bumi ini karena "alam itu sendiri hebat", karena kemampuan dan otonomi alam semesta itu sendiri, karena alam semesta sudah memiliki sistem dan hukumnya sendiri, yakni melalui hukum alam atau hukum mekanik dan teori evolusi atau seleksi alamiah.

Kenyataan seperti itu, menjadikan alam semesta ini hadir tanpa memiliki tujuan, Darwin yang semula adalah seorang yang beragama dan mengakui adanya Tuhan yang mengatur alam, tetapi kemudian justru "meninggalkan" Tuhan dan meyakini "kekuatan" alam. Sehingga dalam tahap berikutnya, hubungan manusia dan alam semesta hanya diatur melalui sains. Dan sains sangat antroposentrisme dan subjektif dalam menerapkan kebijakankebijakan terhadap alam semesta atau lingkungan. Dalam skema singkatnya hubungan segitiga antara alam semesta, manusia dan sains menunjukkan ada ruang yang kosong atau hilang, yakni faktor spiritual, yakni nilai-nilai agama, terutama Tuhan. (Mulyadi Kartanegara, 2009)

Berbeda dengan kaum atheis, bagi kaum deis, mereka mengakui adanya Tuhan, hanya menurut kaum ini, peran Tuhan hanya terbatas pada penciptaan, setelah Tuhan menciptakan alam semesta ini, kemudian alam berjalan secara otonom. Hubungan manusia dan alam semesta menjadi sama saja dengan kelompok pertama, Tuhan tidak berperan lagi dalam mengendalikan alam semesta ini. Pada level tertentu, bagi kelompok ini, do'a juga menjadi tidak berarti apa-apa bagi manusia dalam hubungannya dengan Tuhan dan alam semesta. Dalam skema singkatnya, Tuhan bagi kaum deis, bersifat pasif dan manusia dan alam semesta mengikuti hukum alamnya masing-masing.

Seyyed Hossein Nasr menyebutkan bahwa nature as sacred, artinya alam memiliki nilai spiritual dan nilai religius. Dengan nilai spiritual dan religius itu kemudian menjadikan manusia menjaga dan menghormati alam, sebaliknya apabila nilai kesakralan itu dijauhkan apalagi ditiadakan dari alam, maka manusia mendapat alasan untuk melakukan 
pengrusakan terhadap alam. Penyebab utama dari kerusakan alam dan lingkungan, mulai dari dominasi manusia atas alam, ekploitasi yang dilakukan manusia terhadap alam, alam dijadikan sebagai sumber atau objek materialistik atau dianggap sebagai mesin, adalah hilangnya nilai spiritualitas dan nilai religius dari alam. Artinya hilangnya "peran" Tuhan dari alam, karena pemahaman manusia yang jauh dari Tuhan hingga tidak mempercayai adanya Tuhan, mulai dari nilai sekulerme hingga atheisme. Maka Nasr (2007) mengatakan; "to change that attitude, we have to bring back the sense of the sacred in nature".

Menurut Nasr (2010 : 198), keadaan inilah yang menjadi "penyakit" dan bahaya terbesar yang dihadapi oleh manusia di muka bumi, karena merupakan penyakit dan bahaya terbesar, maka akibatnyapun menjadi yang terbesar yang akan dihadapi oleh umat manusia. Ia menyebutkan bahwa banyak para ilmuan dan filosof kontemporer yang terjebak pada "kedamaian semu", dengan meyakini bahwa bencana besar seperti bahaya nuklir hanya dihasilkan dari perang, oleh karena itu hindari perang dan hiduplah dalam perdamaian. Padahal tanpa disadari bahwa kedamaian yang dipahami saat ini jauh lebih berbahaya daripada perang.
Alasannya, jika terjadi perang mungkin jutaan manusia akan terbunuh di suatu negara, dan itu menjadi pelajaran bagi penduduk negara lain untuk menjaga kehidupan mereka, tetapi dengan manusia menghancurkan alam, terjadinya pemanasan global dan kengerian lain yang diakibatkan oleh "peperangan" kehancuran lingkungan, akan membunuh lebih banyak manusia di muka bumi, tanpa mereka ketahui siapa yang memerangi mereka.

Seyyed Hossein Nasr(1968 : 28-29) menyatakan bahwa abad sekarang ini semakin memperlihatkan arogansi saintifik dan semakin pudarnya metafisika. Hipotesis yang selalu didengungkan seolah-olah satu-satunya bukti kebenaran yang dapat diterima adalah teori-teori ilmiah yang menggambarkan peran sains dan filsafat yang bukan datang dari filsafat spiritualis atau agama tertentu. Fisik material menjadi dogma fisika yang jarang, atau bahkan tidak pernah sama sekali dihubungkan dengan non-fisik, yakni Tuhan. Hipotesis evolusi menjadi dogma biologi yang dihadirkan pada dunia sebagai kebenaran aksiomatik dan lebih lanjut dianggap sebagai sebuah sikap mental yang meresapi semua wilayah, sehingga manusia tidak perlu lagi belajar sesuatu selain evolusi dan sejarahnya. 


\section{PENUTUP}

Begitulah manusia, ketika membicarakan krisis lingkungan dalam perspektif apapun, maka semuanya akan terpulang kepada manusia. Karena manusia sebagai makhluk yang berperan penting dalam mewarnai alam dan lingkungannya. Dengan kemampuan intelektual yang Tuhan anugerahkan kepadanya, manusia dapat mencari dan menempuh jalan mana yang terbaik, untuk dirinya dan untuk alam lingkungannya. Hanya saja manusia kadang tidak menggunakan anugerah rasio tersebut untuk menjalankan tugas ekologisnya dengan baik, manusia bahkan cenderung menjadi makhluk pengganggu. David W. Orr (2002 : 13) mengutip kata-kata George Perkins Marsh, "Man is everywhere a disturbing agent. Wherever he plants his foot, the harmonies of nature are turned to discords"

Manusia merupakan "tumpuan" sekaligus sangat membutuhkan alam semesta, di tangan manusia alam bisa menjadi lebih baik dan sebaliknya di tangan manusia juga alam bisa menjadi hancur dan mengalami keterpurukan. Berbagai penelitian dan pendekatan yang dilakukan menunjukkan bahwa manusialah yang menjadi "aktor intelektual" dari segala krisis lingkungan yang terjadi saat ini. Beberapa sebab filosofis krisis lingkungan dalam perspektif eco-philosophy di atas juga menggambarkan bahwa faktor manusia, khususnya dari aspek pemikiran dan doktrin manusia yakni filsafat, juga menjadi faktor utama penyebab terjadinya kerusakan lingkungan. Sehingga dalam konteks ini harus dibarengi pula dengan menjadikan konsepkonsep filosofis ekologis atau filsafat yang ramah lingkungan dan mengembangkan filsafat yang memiliki orientasi ekologis sebagai nilai-nilai baru ekologis dunia (new world view) sebagaimana nilai-nilai khazanah intelektual filosofis Islam jauh berabad-abad sebelumnya.

Ketika alam semesta ini diserahkan kepada "otonomi" alam, dipercaya kepada dominasi sains atau bahkan diserahkan kepada kreasi manusia, tanpa "peran" dan "campur tangan" Tuhan, maka alam semesta akan berada di ambang kehancuran. Dan ketika alam semesta ini mengalami kerusakan dan kehancuran, maka manusia adalah makhluk pertama yang akan merasakan akibatnya. Karena manusialah yang diberikan kepercayaan oleh Tuhan untuk memilih antara "melibatkan tangan" Tuhan atau "meniadakan peran" Tuhan.

$$
\text { Fritjof Capra }
$$

berpendapat bahwa akar dari krisis lingkungan saat ini adalah world view manusia yang membawa keserakahan terhadap alam semesta, apakah keserakahan tersebut karena kemiskinan, kebodohan atau 
umumnya untuk menghimpun harta kekayaan, hal ini disebabkan oleh kekosongan nilai transendental dalam diri manusia untuk dijadikan acuan moral dalam hidup. Lebih khusus lagi ia menegaskan bahwa musibah yang dihadapi bumi saat terjadi akibat pengembangan sains dan teknologi yang tanpa wawasan spiritual dan jauh dari nilai-nilai Ilahi, sehingga menurutnya ada istilah yang sangat menarik, bahwa manusia telah menghancurkan alam semesta secara teori sebelum menghancurkannya dalam praktek.

Krisis lingkungan hidup global yang dirasakan dan terjadi dewasa ini, sebenarnya bersumber pada kesalahan fundamentalfilosofis dalam pemahaman atau cara pandang manusia mengenai dirinya dan alam semesta, dan tempat manusia dalam keseluruhan ekosistem. Kekeliruan cara pandang ini kemudian melahirkan perilaku yang keliru pula terhadap alam. Manusia keliru memandang alam semesta, dan keliru pula dalam menempatkan diri dalam konteks alam semesta seluruhnya. Karena itu pembenahannya harus pula menyangkut pembenahan cara pandang dan perilaku manusia dalam berinteraksi, baik dengan sesama manusia, dengan alam semesta, maupun terutama interaksi manusia terhadap Tuhan, yang dalam world view filosofis selama ini sering dihilangkan.
Eco-Islamic philosophy merupakan salah satu dari tawaran gerakan lingkungan hidup yang diharapkan dapat menjadi new world view yang mengedepankan kearifan filosofis religius dalam mengubah sikap, gaya hidup dan perilaku manusia untuk menyelamatkan lingkungan hidup dan eksistensi alam semesta. Tantangan yang dihadapi masih sangat besar dan masih membutuhkan energi dan waktu yang lama. Karena mengubah sikap, gaya hidup dan perilaku manusia membutuhkan waktu yang lama. Sementara itu, kerusakan lingkungan hidup terus saja terjadi dengan laju yang semakin cepat. Hanya ada dua pilihan, alam semesta dan lingkungan akan hancur atau manusia berubah sekarang ini juga.

\section{DAFTAR PUSTAKA}

Abdul Quddus, "Islam menjawab Krisis Lingkungan"dalam Jurnal The School, For Advanced Research, Vol. 3. No. 3/Maret 2011. SPS UIN Syarif Hidayatullah Jakarta.

Albert Gore, Jr, Earth in the Balance: Ecology and the Human Spirit (New York: Houghton Mifflin, 1992).

Armely Meiviana, et all, Bumi Makin Panas, Ancaman Perubahan Iklim di 
Indonesia, (Jakarta:

Kementerian Lingkungan

Hidup Republik Indonesia

dan Yayasan Pelangi

Indonesia, 2004).

Arne Naess, Ecology, Comunity and

Lifestyle:Outline

of

Ecosophy

(Cambridge:

Cambridge University Press, 1989).

Bruno Guiderdoni, "Reading God's Sign" dalam W. Mark Richadson and Gordy Slack (Ed), Faith in Science, Scientist Search for Truth (London \& New York: Routledge, 2001),82.

David Ray Griffin, Religion and Scientific Naturalisme, Overcoming the Conflicts (New York: State University of New York Press, 2000)

David W. Orr, The Nature of Design, Ecology, Culture and Human Intention (Oxford \& New York: Oxford University Press, 2002)

Douglas Long, Ecoterrorism (New York: Facts on File, Inc, 2004)

Fritjof Capra, The Tao of Physic, An Exploration of the Parallels Between Modern Physic and Eastern Mysticism (London: Flamingo, 1982)

George Sessions, Deep Ecology for the 21 'st Century (London \& Boston: Shambhala Publications, 1995).
Hadi S. Alikodra, Konservasi

Sumberdaya Alam dan

Lingkungan,Pendekatan

Ecosophy bagi

Penyelamatan Bumi.

(Yogyakarta: Gadjah Mada University Press. 2012)

Henryk Skolimowski, Eco Philosophy: Designing New Tactics for Living (London: Marion Boyars Publishers Ltd, 1981).

Joe Buchdahl, et all, Global Warming (Manchester: Atmosphere, Climate \& Environment Information Programme (ACE), 2002).

Jurgen Moltmann, God in Creation, An Ecological Doctrine of Creation. (London: SCM Press Ltd, 1997)

Keith Ward, God, Chance and Necessity (Oxford: Oneworld, 1996), Edisi Indonesia, Dan Tuhan Tidak Bermain Dadu, Argumen Bagi Keterciptaan Alam Semesta, terj. Larasmoyo (Bandung: Mizan, 2002)

M. Eliade, The Sacred and the Profan, the Nature of Religion (New York: State University of New York Press, 1959)

Mary Evelyn Tucker dan John A. Grim (Ed), Agama, Filsafat dan Lingkungan Hidup,

Mudofir, "Argumen Konservasi Lingkungan Sebagai Tujuan Tertinggi Syari'ah.” Jakarta: 
UIN Syarif Hidayatullah, 2009.

Mulyadhi

Kartanegara,

Mengislamkan Nalar,

Sebuah Respon terhadap

Modernitas (Jakarta:

Penerbit Erlangga, 2009)

Muzaffar Iqbal, Science and Islam

(London: Greenwood Press, 2007).

Nawal Ammar, "Islam and Deep Ecology dalam David

Landill Barhill \& Roger S.

Gottelieb, Deep Ecology And

World Religion, New Essays

on Sacred Ground (New

York: New York University

Press, 2001)

Roy W. Spencer, The Great Global

Warming Blunder, How

Mother Nature Fooled the

World's Top Climate

Scientists (New York \&

London: Encounter Books, 2010)

Sarah McFarland Taylor, Green

Sisters, A Spiritual Ecology

(Cambridge: Harvard

University Press, 2007).

Seyyed Hossein Nasr, The

Encounter of Man and

Nature, The Spiritual Crisis

of Modern Man (London:

George Allen And Ulwin

Ltd, 1968)

, In Search of the Sacred, A

Conversation with Seyyed

Hossein Nasr on His Life and Thought/Seyyed Hossein Nasr with Ramin
Jahanbegloo (California:

ABC-CLIO, LLC, 2010)

Shierry Weber Nicholsen, The Love

of Nature and the End of the World (London \&

Massachusetts: The

Massachusetts Institute of

Technology Press, 2002)

Supian, "Spiritual Ecology (MUI dan Kajian Islam Tentang Lingkungan)", dalam Jurnal Fatwa MUI Pusat, Vol. 1 Nomor 1 Tahun 2011, 171195.

Val Plumwood, Environmental Culture, The Ecological Crisis of Reason (London \& New York: Routledge, 2002)

http://www.counterbalance.org/biol guid-frame.html,

http://www.ecophilosophy.org/new/ articles/090214_history.html,http://h ome.cogeco.ca/ drheault/ee_reading s/Environmental_Ethics_Society/Sk olimowskiWhat is_Eco_philosophy www.jamesgregory.org/.../CVGuide rdon.

www.ecophilosophy.org/new/about. html.

www.ecophilosophy.org/new/histor y.html. 